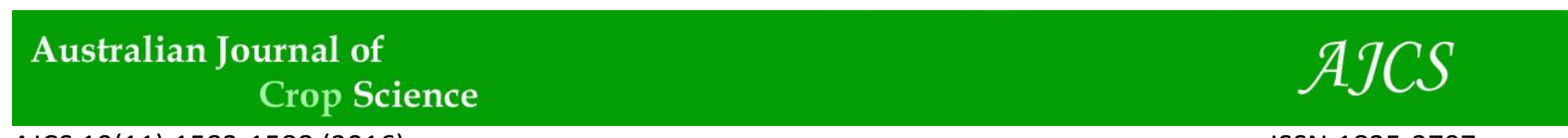

AJCS 10(11):1583-1588 (2016)

ISSN:1835-2707

doi: 10.21475/ajcs.2016.10.11.p7904

\title{
Application effects of biofertilizers on blackleg disease and the development of potato plants
}

\author{
Renato Ribeiro Cardoso, Atalita Francis Cardoso, Roberta Camargos Oliveira, Regina Maria Quintão \\ Lana*, José Magno Queiroz Luz
}

\begin{abstract}
Agrarian Science Institute, Graduate Program in Agronomy, Universidade Federal de Uberlândia - UFU. St. Amazonas n/n, Umuarama Campus. Build 2E. CEP 38400-902. Uberlândia, Minas Gerais, Brazil
\end{abstract}

*Corresponding author: rmqlana@iciag.ufu.br

\begin{abstract}
This study aimed to evaluate the effects of various forms of biofertilizer applications on blackleg disease, Pectobacterium carotovorum subsp. carotovorum (Pcc), as well as the growth and development of potato plants. The experimental design was randomized blocks with the following forms of biofertilizer applications: in-furrow at planting, via foliar, in-furrow at planting + via foliar. The control treatment consisted of foliar applications of a chemical fungicide. In total the experiment consisted of four treatments and five replications. The evaluation of fresh and dry mass of leaves, stems and tubers, the length of the biggest stem, the number of stems and tubers was made via extraction of plants 49,61, 73 and 85 days after planting. The incidence of blackleg disease was obtained by reviews every 15 days with the aid of diagrammatic scale. The harvest was carried out 106 days after planting followed by an evaluation of tuber yield and classification of tubers. The assessed forms of application did not significantly affect the productivity of tubers, which varied from 32-36 tha ${ }^{-1}$. However, the forms of application were significantly correlated with the incidence of the blackleg disease. The results indicate that foliar applications of biofertilizers can considerably control the blackleg disease and positively affect the growth of potato plants.
\end{abstract}

Keywords: Solanum tuberosum, Pectobacterium sp., biofertilizers, tubers, foliar nutrition.

Abbreviations: AUDPC_Area under the disease progress curve; DAP_days after plantating; DML_dry mass of leaves; DMS_dry mass of stems; DMT_dry mass of tubers; FML_fresh mass of leaves; FMS_fresh mass of stems; FMT_fresh mass of tubers; NPK_nitrogen, phosphorus, potassium; NS_ number of stems; NT_ number of tubers.

\section{Introduction}

The potato is a vegetable of a great economic importance. In Brazil it is planted on about 150,000 hectares, producing about 3.6 million tons of tubers (Ibge, 2014). In the management of potato plants special attention should be given to disease control due to the high susceptibility of this culture to a range of pathogens with potentially devastating consequences. Among these pathogens are pectobacteria, Pectobacterium spp, which cause blackleg disease (Tassa and Duarte, 2006). Pectobacterium survive in water, soil, and debris of infected crops in the region of rhizosphere of the host plant. These bacteria spread in potato crops by multiplication of contaminated seed tubers or plant injuries. Pectobacteria survive a wide range of temperatures and are viable for long periods of time. Therefore, chemical control has low efficacy and the development of new products is slow (Gomes et al., 2005). Thus, an integrated management of blackleg should be adopted by combining various measures from planting to the marketing of the tubers (Beriam, 2007; Mello et al, 2011). Among all control measures, chemical control is the most popular in Brazil through a combination of protective and systemic fungicides. However, due to the complexity of the epidemiology of the disease the results have often fallen short of the desired.

Because it is difficult for potato farmers to control the pathogen, there is a need for new integrated management practices aimed at minimizing economic damage caused by pectobacteria, and which are less harmful to the environment as well as to the plant. Among the management methods, the use of biofertilizers is a promising alternative to control blackleg and to promote resistance in plants. The induced resistance has shown potential in the control of plant diseases triggered by microbial, natural and chemical agents. This resistance is expressed locally at the site of pathogen attack and systematically in uninfected parts of the plant (MauchMami and Metraux, 1998). The defense mechanisms engage a combination of physical changes such as cell wall lignification, formation of papillae or induction of various proteins involved in metabolic processes. Advances in research of induced resistance in plants have helped develop new commercial products (Resende et al., 2006). Biofertilizers are liquid organic compounds used as additional source of micronutrients for plants. They can also boost pest and disease resistance in plants due to the presence of toxic substances in their compounds (Pinheiro and Barreto, 1996 ; Nunes and Leal, 2001). Biofertilizer applications in passion fruit produce plants which are higher, with increased diameter, number of branches, flowers and fruits and lower incidence of bacterial and fungal diseases (Collard et al., 2000). Nascimento et al. (2013) found better effectiveness of biofertilizers in relation to chemical fungicides to control anthracnose in tomato. Several studies have found satisfactory effects in disease control with the use of biofertilizers in plants such as watermelon, cucumber, pepper, peas and others (Murphy et al 2003; Barra et al., 
2009; Ling et al. 2011; Ramachandran et al. 2011; Aravindi et al. 2009).

In this context, this study aimed to evaluate the effects of various application forms of biofertilizers on blackleg as well as the growth and productivity of potato.

\section{Results and Discussion}

\section{Incidence of blackleg disease}

The effect of different biofertilizer application methods on the incidence of blackleg varied considerably relative to the chemical fungicide (Table 1). The application of chemical fungicide produced larger area below the progress curve of the disease in relation to the biofertilizer application methods, which was $31 \%$ higher than the in-furrow + foliar application and $40 \%$ higher than the foliar application alone (Table 1). Promising results with the use of biofertilizers were observed in the control of: (i) Xanthomonas axonopodis pv. passiflorae using Agro Mos ${ }^{\mathrm{TM}}$ biofertilizers in yellow passion fruit; (ii) powdery mildew in melon, (iii) alternaria in Mucorte tangerine and (iv) late blight and gray mold in tomatoes (Mesquita et. al 2005; Johsnston et al., 2005; Tosun, 2005; Junqueira et al. 2011).

Biofertilizers generally inhibit the action of pectobacteria in potatoes probably because they contain a copper biocomplex which is fully available for plants (Table 1 and 2). Copper regulates several enzymes involved in plant defense against infections, and also plays an important role in the production of antimicrobial compounds and in general resistance to disease (Ventura and Zambolim, 2012).

Management practices adopted during the development of potato plants in our experiment influenced the incidence of blackleg. Comparing the forms of application we observed that the foliar application was $29 \%$ more effective to control the progression of blackleg relative to the furrow application (Table 1). Copper, which induces the resistance of plants, as already mentioned, has little redistribution in phloem, which may explain the higher efficiency of foliar application because copper in the composition of biofertilizers it is in the form of chelate (Camilo, 2009). Another fact that can increase the efficiency of foliar application is the provision of nutrients which are present in the biofertilizers. These nutrients combined with the nutrients from the soil solution efficiently meet nutritional needs of potato plants during their growth and development (Rocha et al., 2009) (Table 1). The fact that the treatments with foliar applications produced healthier plants is relevant because such practices can be performed with an application of chemical pesticides, commonly used in potato crops.

Biofertilizers are products with considerably low environmental impact. They also induce the resistance of susceptible plants to a broad spectrum of pathogens (Roese et al., 2012). For this reason, their use may become a promising alternative to control blackleg in potatoes and mitigate environmental impacts caused by over-application of pesticides.

\section{Fresh and dry mass of plants}

The foliar applications produced better results regarding fresh mass of leaves stems and tubers, with verified statistical difference for fresh mass of leaves. Maintaining shoots of potatoes (stems + leaves) is essential to obtain high yields of tubers because photosynthates and mineral nutrients are translocated to tubers (Filgueira, 2008). For this reason, the treatment with foliar application increased the fresh mass of tubers by $12 \%$, and by $14 \%$ when the foliar application was combined with the in-furrow application. Similar results were found by Silva et al. (2011) evaluating the development of bean plants on the basis of biofertilizer application. They found higher efficiency of foliar application regarding plant height, the number of leaves per plant and the number of grains per plant comparing with an application to soil.

The assessment made during the sampling periods showed quadratic interaction of fresh mass of leaves and stems with maximum accumulation of 400.66 and $201.39 \mathrm{~g} \mathrm{plant}^{-1} 65$ and 71 DAP, respectively. Fernandes et al. (2010) observed growth of stems and leaves of Asterix cultivar up to 69 DAP, a result similar to the present study. The fresh mass of tubers showed growth by $36.69 \mathrm{~g} \mathrm{plant}^{-1}$ each day after planting (Figure 1).

Dry mass of leaves, stems and tubers ranged from $30-40$, 12 - 15 and $185-222$ g plant $^{-1}$, respectively (Table 3 ). It can be seen that potato plants treated with biofertilizers showed higher dry mass of leaves, stems and tubers relative to plants treated with the chemical fungicide, which enhances the efficiency of biofertilizers to control blackleg (Table 3).

Dry mass of leaves and stems produced a quadratic function. It shows an accumulation of 40.9 and 17.48 g plant $^{-1}$ of dry mass of leaves and stems 67 and 65 DAP, respectively, and further decrease. With the growth of tubers, there is a change in the distribution of dry matter among the organs of the plant. The accumulation of dry matter in shoots is reduced, photoassimilates are drained to the tubers and the plant as a whole starts entering senescence phase (Coraspe-Leon et al, 2009; Silva et al, 2010). The tubers were the main drains 61 DAP. Dry matter accumulation in tubers increased reaching the maximum $254.15 \mathrm{~g} \mathrm{plant}^{-1} 85 \mathrm{DAP}$. Fernandes et. al (2010), Barcelos et. al (2007) and Yorinori (2003) also observed decreased accumulation in leaves and stems as potato plants reached maturity (Fig $2 \mathrm{a}$ ).

\section{Height, number of stems and tubers}

Height, the number of stems and tubers were not influenced by the treatments (Table 3 ). The plants had 4 to 5 stems 71 $75 \mathrm{~cm}$ long producing 11 to 13 tubers. The number of stems produced by each plant is directly associated with the size of seed tubers as well as sprouting after planting (Feltran and Lemos, 2005).

The number of stems and tubers increased during the potato growth cycle reaching the maximum of 5.45 and 13.15 , respectively. The maximum length of stems $(74.04 \mathrm{~cm})$ was observed 76.58 DAP (Fig 3a). It is noteworthy that potato productivity is constrained by the number of stems per area from well-sprouted tubers or smaller spacing between tubers. More stems produce more tubers, but of smaller diameter (Bussan et al., 2007; Filgueira, 2008).

\section{Yield and classification of tubers}

There was no significant interaction among the application methods of biofertilizers, the fungicide, and the harvest period with respect to the growth, yield and classification of tubers (Table 4). Although no statistical difference was observed, it was noted that the number of tubers classified as Special was $21 \%$ higher with the foliar application of biofertilizer relative to the in-furrow application, reaching a difference of $3.74 \mathrm{tha}^{-1}$ (Table 4). Importantly, in the 
Table 1. The area under the disease progress curve (AUDPC) for different forms of management of blackleg disease.

\begin{tabular}{ll}
\hline Application & AUDPC \\
\hline Fungicide via foliar & $913.8 \mathrm{c}$ \\
Biofertilizer in-furrow & $770.7 \mathrm{~b}$ \\
Biofertilizer via foliar & $543.6 \mathrm{a}$ \\
Biofertilizer in-furrow + via foliar & $624.7 \mathrm{a}$ \\
\hline Mean & 713.2 \\
CV $(\%)$ & $9.63 \%$ \\
\hline *Means followed by the same lowercase letters in the column do not differ by Tukey test at 5\%
\end{tabular}

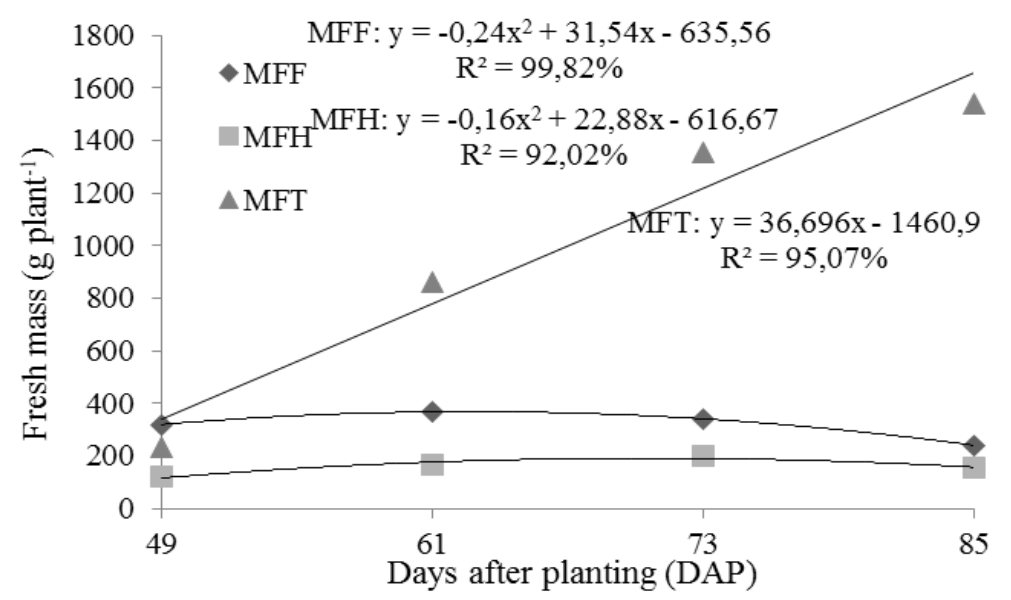

Fig 1. Fresh mass of leaves (FML), fresh mass of stems (FMS) and fresh mass of tubers (FMT) of potato plants with respect to days after planting.

Table 2. Fresh mass of leaves (FML), fresh mass of stems (FMS) and fresh mass of tubers (FMT) of potatoes for different forms of management of blackleg disease.

\begin{tabular}{lccc}
\hline Application & FML & FMS & FMT \\
\hline & & g plant $^{-1}$ & \\
\hline Fungicide via foliar & $263,80 \mathrm{~b}$ & $147,30 \mathrm{a}$ & $930.87 \mathrm{a}$ \\
Biofertilizer in-furrow & $308,15 \mathrm{ab}$ & $161,36 \mathrm{a}$ & $901.67 \mathrm{a}$ \\
Biofertilizer via foliar & $336,65 \mathrm{ab}$ & $164,37 \mathrm{a}$ & $1067.49 \mathrm{a}$ \\
Biofertilizer in-furrow + via foliar & $358,05 \mathrm{a}$ & $164,37 \mathrm{a}$ & $1090.99 \mathrm{a}$ \\
\hline MAD & 76,62 & 43,05 & 258.26 \\
CV $(\%)$ & 28,95 & 32,32 & 30.97 \\
\hline
\end{tabular}

* Means followed by the same lowercase letters in the column do not differ by Tukey test at 5\%. MAD: mean absolute deviation
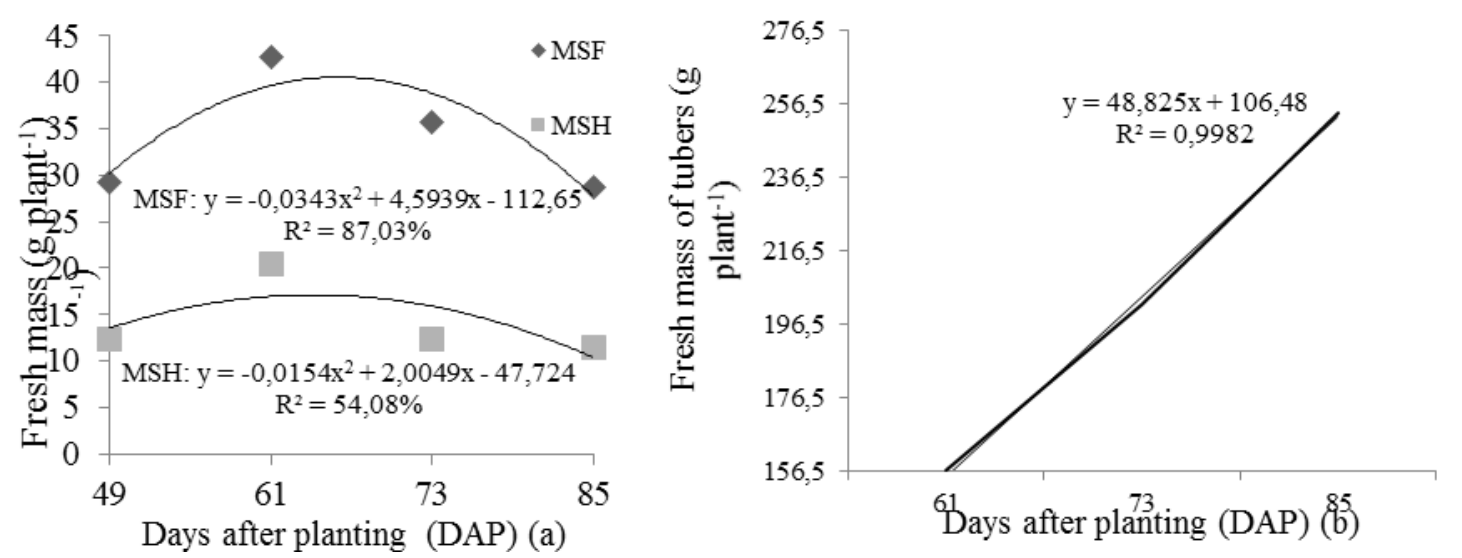

Fig 2. Dry mass of leaves, dry mass of stems (a) and dry mass of tubers (b) with respect to days after planting. 
Table 3. Plant height, number of stems (NS) and tubers (NT), and dry mass of leaves (DML), stems (DMS) and tubers (DMT) of potatoes for different forms of management of blackleg disease.

\begin{tabular}{|c|c|c|c|c|c|c|}
\hline Application & $\begin{array}{c}\text { Height } \\
\mathrm{cm}\end{array}$ & \multicolumn{4}{|c|}{ Amount (g plant ${ }^{-1}$ ) } & DMT \\
\hline Fungicide via foliar & $71.82 \mathrm{a}$ & $4.90 \mathrm{a}$ & $11.20 \mathrm{a}$ & $30.14 \mathrm{a}$ & $12.96 \mathrm{a}$ & $187.8 \mathrm{a}$ \\
\hline Biofertilizer in-furrow & $74.20 \mathrm{a}$ & $5.05 \mathrm{a}$ & $12.20 \mathrm{a}$ & $30.46 \mathrm{a}$ & $15.62 \mathrm{a}$ & $205.3 \mathrm{a}$ \\
\hline Biofertilizer via foliar & $75.40 \mathrm{a}$ & $4.85 \mathrm{a}$ & $11.50 \mathrm{a}$ & $34.98 \mathrm{a}$ & $14.47 \mathrm{a}$ & $200.7 \mathrm{a}$ \\
\hline Biofertilizer in-furrow + via foliar & $71.95 \mathrm{a}$ & $4.85 \mathrm{a}$ & $12.55 \mathrm{a}$ & $40.73 \mathrm{a}$ & $13.60 \mathrm{a}$ & $222.8 \mathrm{a}$ \\
\hline MAD & 5.88 & 1.42 & 3.16 & 12.38 & 4.26 & 66.72 \\
\hline $\mathrm{cv}(\%)$ & 9.60 & 34.64 & 31.89 & 43.46 & 36.03 & 33.51 \\
\hline
\end{tabular}

* Means followed by the same lowercase letters in the column do not differ by Tukey test at 5\%. MAD: mean absolute deviation
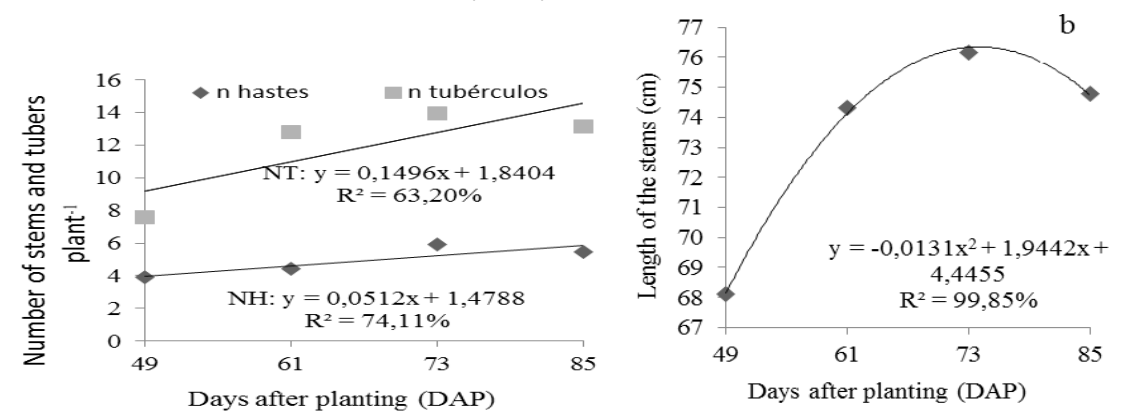

Fig 3. Number of potato stems and tubers (A) and height of the stems (B) of potato plants with respect to days after planting.

Table 4. Clasification, commercial and total productivity of potato tubers for different forms of management of blackleg disease.

\begin{tabular}{lccccccc}
\hline Application & Special & Second & Diverse & $\begin{array}{c}\text { Lollipop } \\
\mathrm{t} \mathrm{ha}^{-1}\end{array}$ & Discard & Jumbo & Total \\
\hline Fungicide & $16.20 \mathrm{a}$ & $17.68 \mathrm{a}$ & $1.80 \mathrm{a}$ & $0.31 \mathrm{a}$ & $4.25 \mathrm{ab}$ & $0.67 \mathrm{ab}$ & $40.93 \mathrm{a}$ \\
In-furrow & $13.30 \mathrm{a}$ & $14.60 \mathrm{a}$ & $3.00 \mathrm{a}$ & $0.20 \mathrm{a}$ & $5.45 \mathrm{a}$ & $1.01 \mathrm{ab}$ & $37.57 \mathrm{a}$ \\
Via foliar & $17.04 \mathrm{a}$ & $9.41 \mathrm{~b}$ & $2.04 \mathrm{a}$ & $0.37 \mathrm{a}$ & $4.21 \mathrm{ab}$ & $1.54 \mathrm{a}$ & $34.62 \mathrm{a}$ \\
In-furrow + foliar & $12.78 \mathrm{a}$ & $18.37 \mathrm{a}$ & $1.48 \mathrm{a}$ & $0.22 \mathrm{a}$ & $2.61 \mathrm{~b}$ & $0.09 \mathrm{~b}$ & $35.55 \mathrm{a}$ \\
\hline MAD & 4.95 & 3.97 & 1.79 & 0.31 & 2.77 & 1.31 & 7.38 \\
CV $(\%)$ & 20.61 & 16.33 & 15.03 & 19.23 & 14.51 & 26.12 & 12.27 \\
\hline
\end{tabular}

*Means followed by the same lowercase letters in the column do not differ by Tukey test at 5\%. MAD: mean absolute deviation

Table 5. Doses, number of applications and the period of biofertilizer application.

\begin{tabular}{lcccc}
\hline Application & Biofertilizer & Doses & $\begin{array}{c}\text { Number of } \\
\text { applications }\end{array}$ & $\begin{array}{c}\text { Period } \\
\text { DAP* }\end{array}$ \\
\hline In-furrow & Compost-Aid® & $3.0 \mathrm{~kg} \mathrm{ha}^{-1}$ & 1 & $\begin{array}{c}\text { At planting } \\
\text { At planting }\end{array}$ \\
\hline Foliar & Soil-Set & $2.01 \mathrm{ha}^{-1}$ & 1 & 44 \\
& Compost-Aid® $^{\mathrm{TM}}$ & $1.5 \mathrm{~kg} \mathrm{ha}^{-1}$ & 1 & 66 and 76 \\
& CopperCrop $^{\mathrm{TM}}$ & $0.31 \mathrm{ha}^{-1}$ & 2 & 44,66 and 76 \\
& Soil-Set $^{\mathrm{TM}}$ & $1.01 \mathrm{ha}^{-1}$ & 3 & 44,59 and 73 \\
\hline
\end{tabular}

Table 6. Composition of biofertilizers.

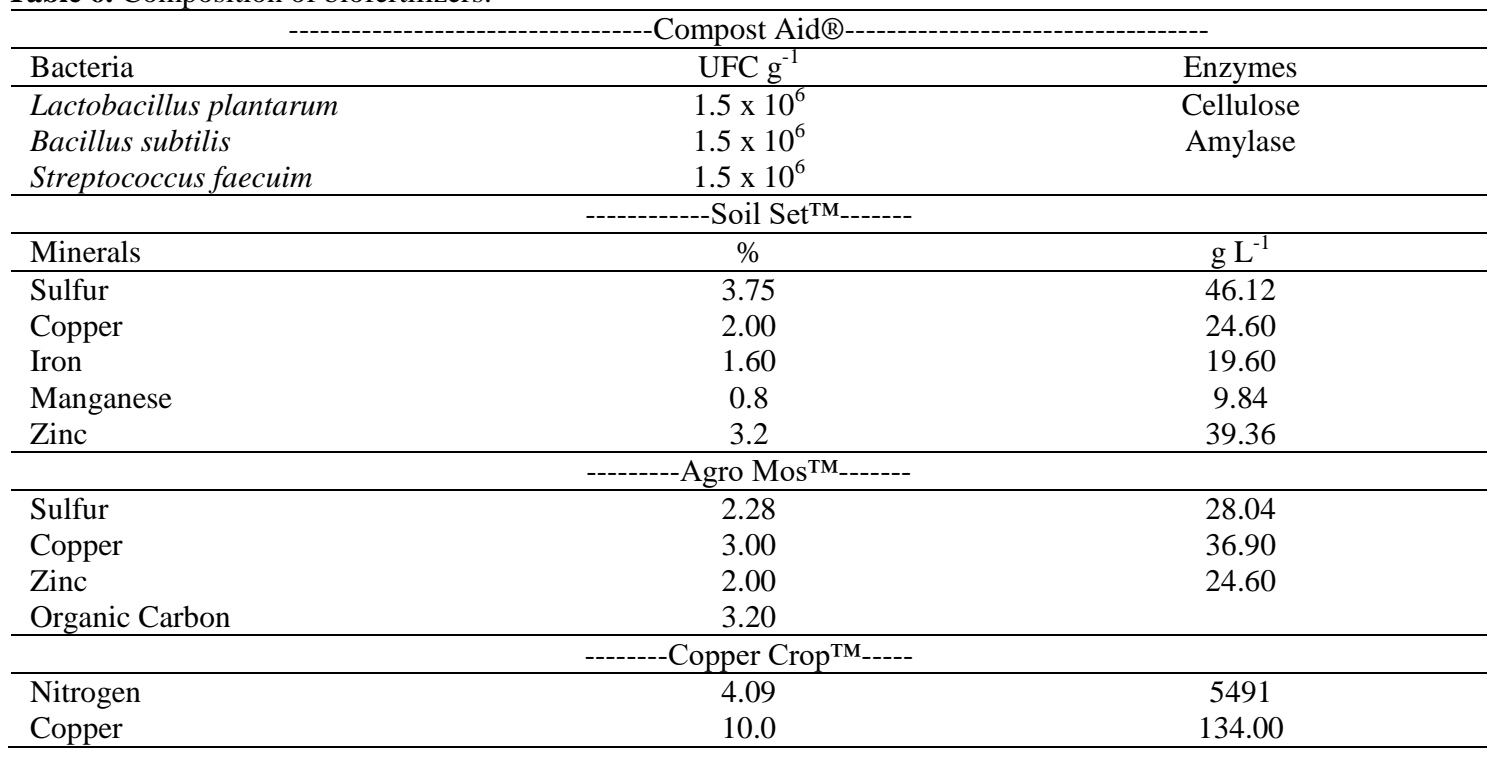


production of tubers a diameter greater than $42 \mathrm{~mm}$ is a desired class (Pereira and Campos, 1999).

Further, we observed that the foliar application produced less tubers classified as Discard, which corroborates the results found in this study regarding the development traits of potato plants (Tables 2 and 3). The use of biofertilizers to control blackleg in potatoes can be beneficial even for the storage period of tubers. During post-harvest, under favorable temperature and moisture conditions, there is a rapid decay of tubers with pectobacteria in a latent stage considerably reducing storage time (Paiva, 1997). The disease can spread quickly through contact between infected and healthy tubers, leading to losses before and after classification (Beneli et al. 2004). The overuse of chemical pesticides in agriculture promotes the contamination of natural resources, damaging the quality of life of rural and urban populations (Caporal and Costabeber, 2004). In this context, the consumer market has created a demand for healthier foods which are produced with minimal impact on the environment. Therefore, the incorporation of sustainable production practices is essential to meet these requirements.

\section{Materials and Methods}

\section{Experimental site and the plant material}

The experiment was conducted between February 16 and May 31, 2012 on Fazenda Lagoinha, Minas Gerais, located at $19^{\circ} 05^{\prime} \mathrm{S}$ and $47^{\circ} 20^{\prime} \mathrm{W}$, at an altitude of $1050 \mathrm{~m}$.

Before the deployment of the experiment soil samples were collected from the layer of $0-20 \mathrm{~cm}$ for chemical analyzes, conducted according to the methodology of Embrapa (2011). The soil presented the following characteristics: $\mathrm{pH}\left(\mathrm{H}_{2} \mathrm{O}\right)=$ 5.8; $\mathrm{P}=1.7 \mathrm{mg} \mathrm{dm}^{-3} ; \mathrm{K}^{+}=27 \mathrm{mg} \mathrm{dm}{ }^{-3} ; \mathrm{Ca}^{2+}=9 \mathrm{mmol} \mathrm{dm}^{-3}$; $\mathrm{Mg}^{2+}=5 \mathrm{mmol} \mathrm{dm}{ }^{-3}$; organic matter $=1.7 \%$; base saturation $=50 \%$; and cation exchange capacity $=3.12 \%$.

The soil in the experimental area was prepared with two plowings followed by a harrowing. Potato seed tubers 30 to $40 \mathrm{~mm}$ in diameter of Cupid III cultivar were used.

\section{Preparation and application of treatments}

The experimental design was randomized blocks, with four treatments and five repetitions. The experimental plots were composed of 8 rows each $10 \mathrm{~m}$ long and $0.8 \mathrm{~m}$ apart, with a total area of $64 \mathrm{~m}^{2}$. The treatments consisted of the following forms of applications: into the furrows at planting, via foliar, into the furrows at planting + via foliar, and the control with a foliar application of a chemical fungicide, Agrimicina ${ }^{\circledR}$ (oxitetraciclina + streptomycin sulfate), at a dose $2.4 \mathrm{~kg} \mathrm{ha}^{-1}$ (Table 5). The treatments with the application of biofertilizers into the furrows at planting were done using one application of Compost-Aid® $\left(3.0 \mathrm{~kg} \mathrm{ha}^{-1}\right)$ and one application of Soil$\mathrm{Set}^{\mathrm{TM}}\left(2.01 \mathrm{ha}^{-1}\right)$.

Hilling of the plants to stimulate tuberization and fertilization with $300 \mathrm{~g} \mathrm{~m}^{-1}$ of 10-00-10 NPK fertilizer applied into the furrows were done 30 DAP. The treatments with foliar application of biofertilizers consisted of one application of Compost-Aid ${ }^{\circledR}\left(1.5 \mathrm{~kg} \mathrm{ha}^{-1} 44 \mathrm{DAP}\right)$, two applications of CopperCrop ${ }^{\mathrm{TM}}\left(0.31 \mathrm{ha}^{-1} 66\right.$ and 76 DAP $)$, three applications of Soil-Set ${ }^{\mathrm{TM}}\left(1.01 \mathrm{ha}^{-1} 44,66\right.$ and 76 DAP) and three applications of Agro-Mos ${ }^{\mathrm{TM}}\left(1.01 \mathrm{ha}^{-1} 44,59\right.$ and $73 \mathrm{DAP})$. The treatments with the in-furrow + via foliar applications were done using all rates and products described above. The composition of each biofertilizer is described in table 6. Plant samples were collected 49, 61, 73 and 85 DAP to evaluate the number of tubers and stems, the length of the longest stem and fresh mass of leaves, stems and tubers. Dry mass was obtained by drying the samples in an oven with forced air circulation at $65^{\circ} \mathrm{C}$ for 96 hours.

The incidence of blackleg was obtained by ratings every two weeks from the first symptoms of the disease until the senescence of the plants. Quantification of the severity of the disease obeyed visual criteria and was defined as a percentage of shoots covered with symptoms of the disease. The evaluations were carried out using a diagrammatic scale (Godoy et al., 2006). The evaluations were performed on the $2^{\text {nd }} ; 3^{\text {rd }} ; 6^{\text {th }}$ and $7^{\text {th }}$ row of each parcel excluding $0.5 \mathrm{~m}$ from each end (total area $28.8 \mathrm{~m}^{2}$ ). The average severity values from each plot were used to calculate the area under the disease progress curve (AUDPC) (Campbell and Madden, 1990). The harvest took place 106 DAP. The tubers were collected from the fourth and the fifth row to evaluate the yield and to classify the tubers, disregarding $0.5 \mathrm{~m}$ from each end (total area $14.40 \mathrm{~m}^{2}$ ).

\section{Statistical analysis}

The data were subjected to the analysis of variance and regression ( $\mathrm{F}$ test), at 0.05 significance. Productivity, classification and incidence of blackleg were evaluated comparing the means by Tukey test. Statistical analyses were done using SISVAR software (Ferreira, 2010).

\section{Conclusions}

The application of biofertilizers is effective in reducing the incidence of blackleg disease.

The application of biofertilizers via foliar alone or when combined with in-furrow application provide better development of potato plants.

The plants reached vegetative peak 69 days after planting in the production of dry matter in shoots and also increased dry matter accumulation in tubers.

\section{Acknowledgements}

To Fapemig for financial support of this research, to Rochetto group for providing the site for the experiment, and Improcrop for supplying biofertilizers.

\section{References}

Aravind R, Kumar A, Eapen SJ, Ramana KV (2009) Endophytic bacterial flora in root and stem tissues of black pepper (Piper nigrum L.) genotype: isolation, identification and evaluation against Phytophthora capsici. Lett Appl Microbiol 48:58-64.

Barcelos DM, Garcia A, Maciel Júnior VA (2007) Análise de crescimento da cultura da batata submetida ao parcelamento da adubação nitrogenada em cobertura, em um latossolo vermelho-amarelo. Ciência e Agrotecnologia 31: 21-27

Barra VR, Romeiro RS, Garcia FAO, Moura AB, Silva HSA, Mendonça HL, Halfeld Vieira BA (2009) Antagonismo direto e biocontrole da podridão mole do tomateiro pelo uso de procariotas. Pesq Agropecuária Bras. 44: 327-330.

Benelli AIH, Denardin ND, Forcelini CA, Duarte V (2004) Reação de cultivares de batata à podridão mole causada por Pectobacterium carotovorum subsp. atrosepticum, por $\mathrm{P}$. carotovorum subsp. carotovorum e por P. chrysanthemi. Fitopatologia Brasileira. 29: 155-159.

Beriam LOS (2007) Arquivos do instituto biológico In: Doenças bacterianas em hortaliças. $2^{\text {nd }}$ Ed. Instituto biológico, São Paulo. 
Bussan AJ, Mitchell PD, Copas ME, Drilias M J (2007) Evaluation of the effect of density on potato yield and tuber distribution. Crop Sci. 47:2462-2472.

Camilo FR (2009) Indutores de resistência contra a vassoura de bruxa no cacaueiro. Mecanismo de ação e avaliação em campo. PhD Thesis. Universidade Federal de Lavras.

Campbell CL, Madden LV (1990) Introduction to plant disease epidemiology. New York: Wiley, 532p.

Caporal FR, Costabeber JA (2001) Segurança alimentar e agricultura sustentável: uma perspectiva agroecológica. Ciência Tecnologia. 21: 153-165.

Collard FH, Almeida A, Costa MCR, Rocha MC (2001) Efeito do uso de biofertilizante agrobio na cultura do maracujazeiro amarelo (Passiflora edulis f. flavicarpa Deg). Revista Biociências. 7: 15-21.

Coraspe-León HM, Muraoka T, Franzini VI, Piedade SA de S, Granja N do P (2009) Absorción de macronutrientes por plantas de papa (Solanum tuberosum L.) em la producción de tubérculo-semilla. Interciencia. 34: 57-63.

Embrapa (2011). Manual de análise de solo. 2a . Ed. Rio de Janeiro, RJ, Brazil. Embrapa Solos.

Feltran JC, Lemos LB (2005) Características agronômicas e distúrbios fisiológicos em cultivares de batata. Científica. 33: 106-113.

Fernandes AM; Soratto RP, Silva BL, Schlick-Souza GD (2010) Crescimento, acúmulo e distribuição de matéria seca em cultivares de batata na safra de inverno. Pesquisa. Agropecuária Bras. 45:826-835.

Ferreira DF. 2008. SISVAR: a computer statistical analysis system. Ciência e Agrotecnologia. 35: 1039-1042.

Filgueira FA (2008) Novo manual de olericultura: agrotecnologia moderna de produção e comercialização de hortaliças. 3a Ed. Viçosa, MG, Brazil. Editora UFV.

Godoy CV, Koga LJ, Canteri MG (2006) Diagrammatic scale for assessment of soybean rust severity. Fitopatologia Brasileira. 31: 63-68.

Gomes Ama, Silveira Eb, Mariano RLR (2005) Tratamento póscolheita com cálcio e microrganismos para controle da podridão-mole em tomate. Horticultura Brasileira 23: 108-111.

Ibge. Produção agrícola municipal 2014-2015 (2016) Available at:

http://www.ibge.gov.br/home/estatistica/indicadores/agropecua ria/lspa/lspa_201404_5.shtm. Accessed on February 12, 2014.

Johnstont RRF, Timmer LW (2005) Evaluation of products for control of Alternaria Brown Spot on Murcott Tangor. Florida, USA, IFAS.

Junqueira KP, Faleiro FG, Uesugi CH, Junqueira NTV, Bellon GS, Santos EC dos, Ramos LN (2011) Desempenho agronômico de maracujazeiros tratados com produtos alternativos e fertilizantes foliares. Revista Brasileira de Fruticultura Desempenho agronômico de maracujazeiros tratados com produtos alternativos e fertilizantes foliares. Revista Brasileira de Fruticultura. 33: 40-47.

Ling N, Huang Q, Guo S, Shen Q (2011) Paenibacillus polymyxa SQR-21 systemically affects root exudates of watermelon to decrease the conidial germination of Fusarium oxysporum f.sp. niveum. Plant Soil. 341:485-493.

Mauch-Mani B, Metraux JP (1998) Salicylic acid and systemic acquired resistance to pathogen attack. Annal Bot. 82: 535540 .

Mello MRF, Silveira EB, Viana IO, Guerra ML, Mariano RLR (2011) Uso de antibióticos e leveduras para controle da podridão-mole em couve-chinesa. Horticultura Brasileira 29: 78-83.

Mesquita LX, Sales Junior R, Nascimento MT, Correia KC, Freitas LS, Ferreira HA (2005) Efeito de diferentes elicitores no controle do oídio do meloeiro. Fitopatologia Brasileira. 30: $102-103$
Murphy JF, Reddy MS, Ryu CM, Kloepper JW, LI R (2003) Rhizobacteria mediated growth promotion of tomato leads to protection against cucumber mosaic virus. Phytopathol. 93:1301-1307.

Nascimento AR, Fernandes PM, Borges LC, Moita AW, Quezado-Duval AM (2013) Controle químico da manchabacteriana do tomate para processamento industrial em campo. Horticultura Brasileira. 31: 15-24.

Nunes Muc, Leal MLS (2001) Efeitos da aplicação de biofertilizante e outros produtos químicos e biológicos, no controle da broca pequena do fruto e na produção do tomateiro

tutorado em duas épocas de cultivo e dois sistemas de irrigação. Horticultura Brasileira.19: 53-59.

Paiva HF (1997) Influência das adubações nitrogenada e potássica na incidência de Erwinia spp e Alternaria solani (Ell. .\& Smart.) Jones \& Grout na cultura da batata (Solanum tuberosum L.). MsC Dissertation. Universidade Federal de Lavras.

Pereira AR, Machado EC (1987) Análise quantitativa do crescimento de comunidades vegetais. Boletim técnico $\mathrm{n}^{\circ} 114$. Campinas: Instituto Agronômico de Campinas. 1987. 33p.

Pereira A da S, Campos AD (1999) Teor de açúcares redutores em genótipos de batata (Solanum tuberosum L.). Ciência Rural. 29: 13-16.

Pinheiro S, Barreto SB (1996) MB-4, Agricultura sustentável, trofobiose e biofertilizantes. Ciudade de La Havana, Cuba. Ed. Revolucionaria.

Ramachandran VK, East AK, Karunakaran R, Downie JA, Poole SP (2011) Adaptation of Rhizobium leguminosarum to pea, alfalfa and sugar beet rhizosphere investigated by comparative transcriptomics. Genome Biol. 12:106-109.

Resende MLV, Araujo DV, Costa JCB, Deuner CC, Ferreira JB, Muniz MFS, Reis SN, Santos FS, Cavalcanti LS, Nojosa GBA (2006) Produtos comerciais à base de bioindutores de resistência em plantas. Revisão Anual de Patologia de Plantas. 14:361-380.

Roese A D, Melo CLP, Goulart ACP (2012) Espaçamento entre linhas e severidade da ferrugem asiática da soja. Summa Phytopathologica. 38: 300-305.

Rocha ABO, Lourenção AL, Miranda Filho HS, Hayashi PCR, Ramos VJ (2012) Resistência de clones de batata a Bemisia tabaci biótipo B. Horticultura Brasileira, 30: 32-38.

Silva VF da, Moraes JC, Melo BA (2010) Influence of silicon on the development, productivity and infestation by insect pests in potato crops.Ciência e Agrotecnologia. 34: 1465-1469.

Silva FLB, Lacerda CF, Souza GG, Neves ALR, Silva LG, Souza CHC (2011) Interação entre salinidade e biofertilizante bovino na cultura do feijão de corda. 15: 383-389.

Tassa S ; Duarte V (2006) Identificação de Pectobacterium carotovorum subsp. brasiliensis através de PCR-RFLP do Gene recA. Fitopatologia Brasileira. 31: 23-28.

Tosun N (2005) O papel dos ativadores de plantas no controle de doenças em estufas. In: Simposio Agronômico brasileiro, Instituto Agronômico do Paraná, Curitiba, 2005, 6-10 2005.

Ventura JA, Zambolim L Controle das doenças do abacaxizeiro. In: Zambolim L. Cultura das fruteiras, Viçosa, 2002, v.1, p445509.

Yorinori GT (2003) Curva de crescimento e acúmulo de nutrientes pela cultura da batata cv. 'Atlantic'. MsC Dissertation. Escola Superior de Agricultura Luiz de Queiroz. 